cals. The stack location is given for each periodical. A limited number of copies are available at $\$ 2.00$ each. Purchase requests should be sent to: The Tarlton Law Library, School of
Law, University of Texas, 2500 Red River Street, Austin, Texas 78705. Checks should be made payable to University of Texas Law School Foundation-Library.

\title{
News From the Sections
}

\section{JUNIOR COLLEGE LIBRARIES SECTION}

- The Junior College Libraries Section of the Association of College and Research Libraries is sponsoring a preconference "Merging Materials: A Total Approach to Instruction," at Detroit, Michigan, June 26-27, 1970. The two days of sessions will include panel discussions and small group sessions. Dr. B. Lamar Johnson, Professor of Higher Education, University of California, Los Angeles, will be the keynote speaker at the banquet. There will also be a special workshop on Proposal Writing.

Attendance is limited to 250 persons. The registration fee is $\$ 50.00$. For further information write to: J. Donald Thomas, Executive Secretary, Association of College and Research Libraries, American Library Association, 50 East Huron Street, Chicago, Illinois 60611.

\section{LAW AND POLITICAL SCIENCE SUBSECTION}

- The Preconference Institute "Workshop on Legal Bibliography" scheduled for Detroit has been cancelled, it was announced by the Law and Political Science Subsection of the Association of College and Research Libraries. The Institute was scheduled for June 26-27, 1970 , at the Wayne State University Law School in Detroit prior to the Annual Conference of the American Library Association. All registration fees will be refunded. It will be the responsibility of the registrants to cancel their housing arrangements.

The Association of College and Research Libraries sincerely regrets this inconvenience to all members who had made plans to attend.

- "Government Publications: New Directions in Content, Dissemination and Control" will be the focal point of panel discussions at the ALA Conference in Detroit. Scheduled for Monday, June 29, at 2:00 P.M., and sponsored by the Subject Specialists Section and its Law and Political Science Subsection, the panels will touch on government information programs at every level, local, state, and fed- eral, with emphasis on recent developments and on association participation in their improvement. The meeting will be open to all attending the Conference, and the program will be designed not only for documents librarians but also for all potential users of government information. If that includes you, plan to attend.

\section{RAREBOOKS SECTION}

- "The Private Collector of Books and Manuscripts" will be the theme of a preconference sponsored by the Rare Books Section of the Association of College and Research Libraries at Detroit, Michigan, from June 2527. Planned to provide a much deserved recognition of the importance of the private collector to the world of books and scholarship, it is a natural followup to the program on the antiquarian book trade held several years ago. Major presentations will be made by Charles Feinberg, Charles Blockson, William H. Bond, James D. Hart, Harry Moore, Harrison Hayford, Frederick Goff, C. E. Frazer Clark, James B. Meriwether, Robert Taylor, Gordon Banks, Stuart Schimmel, Kenneth Rendell, Karl Ruhe, and Howell Heaney.

Attendance is limited to 150 , and the registration fee is $\$ 50.00$. Further information and applications may be obtained from: J. Donald Thomas, Executive Secretary, Association of College and Research Libraries, American Library Association, 50 East Huron Street, Chicago, Illinois 60611 .

- The Committee on Manuscript Collections of the Rare Books Section of ACRL will hold a program on the "Administration of Manuscript Collections in Colleges and Universities" during the ALA Annual Conference in Detroit, June 28-July 4.

The program will be held on Monday, June 29, from 2:00 to 4:00 P.M. The panelists will be Mattie Russell, Duke University; Philip P. Mason, Wayne State University; Ruth Salisbury, University of Pittsburgh; Wayne C. Mann, Western Michigan University; and James M. Babcock, Alma College, chairman of the panel. The program is open to the public. 


\section{LENDING LIBRARY of}

\section{FILMS}

\section{SLIDES}

\section{TAPES}

\section{PHOTOS}

\section{RECORDS}

\section{EXHIBITS}

\section{FILMSTRIPS}

\section{SCIENTIFIC FILMS}

\section{on FRANCE}

Catalogue upon request

\section{F. A. C. S. E. A.}

972 5th Avenue, New York City 10021 (212) RE 7-9700

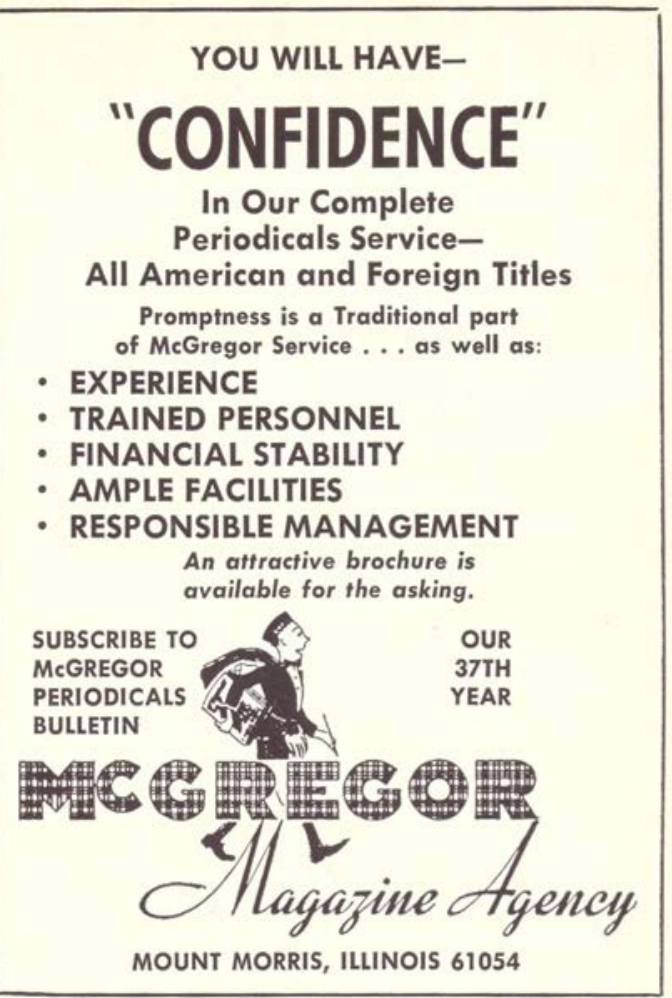

\section{"CONFIDENCE"}

In Our Complete

Periodicals Service-

All American and Foreign Titles

Promptness is a Traditional part

of McGregor Service . . . as well as:

- EXPERIENCE

- TRAINED PERSONNEL

- FINANCIAL STABILITY

- AMPLE FACILITIES

- RESPONSIBLE MANAGEMENT

An attractive brochure is

available for the asking.

MOUNT MORRIS, ILLINOIS 61054

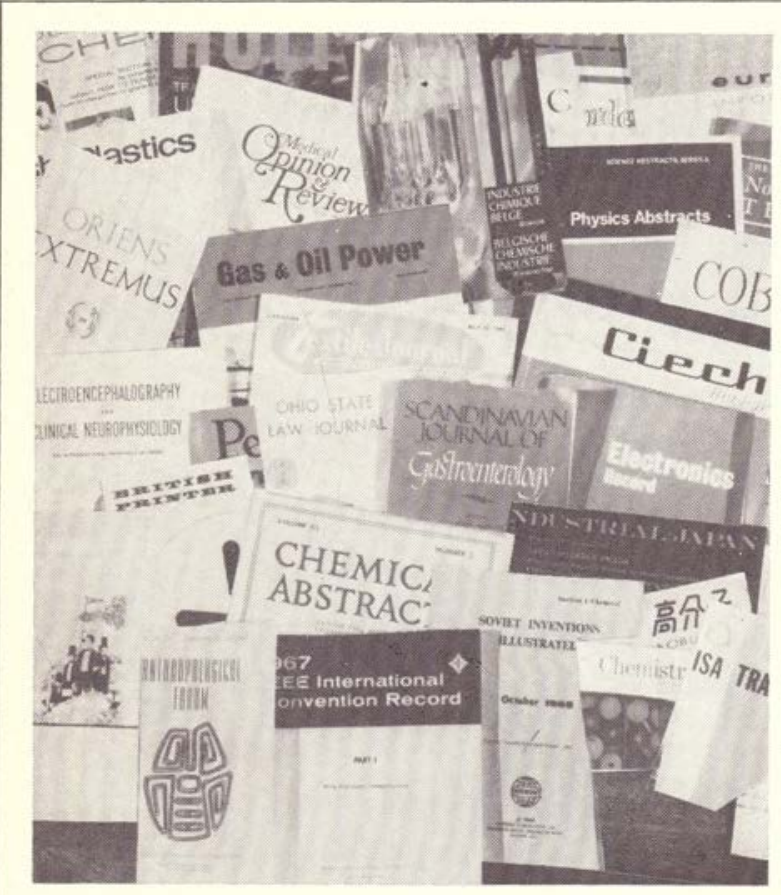

\section{SERVICE UNSURPASSED}

The very best serial subscription serv. ice available-decentralized for more personal attention. A superior listing of both domestic and foreign titles.

\section{EBSCO SUESCRIPTION SERVICES}

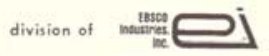

E8SCO Building Sart. Northwest Highwa (312) $381-2190 / 381-219$

512 Nicollet Building Minneapolis, Minnesota 55402 (612) 333.5081

540 Granite Street Braintree, Massachusetts 0218 617) $843.2383 / 843.2384$

681 Market Street San Francisco, California 94105 (415) $319-3500$

1230 First Avenue North Birmingham, Alabama 35203 (205) 323.6351
415 Douglas Plaza Bldz. Dallas, Texas 75225 (214) $369.7591 / 369.7592$ EBSCO Buildins. Red Bank, New Jersey 0770 201) $741-4300$

P. 0. Box 92901 Cos. Angeles, California 90009 213) 772.238

Room 245

Continental Terrace Buildine 2785 North Speer Boulvear Denver, Coliorado 80211 R 


\section{THE BAKER \& TAYLOR CO. \\ Oldest and Largest Book Wholesaler in the U.S.}

\section{- 5,000,000 BO0KS IN 4 REgIONAL WAREHOUSES}

- OVER 120,000 TITLES (SOON TO BE 200,000) FROM 1,500 PUBLISHERS

- BIGGEST INVENTORY OF UNIVERSITY PRESS BOOKS

- MOST COMPLETE, FASTEST FIRST SHIPMENT SERVICE

New service programs from Baker \& Taylor

University \& College Library New-Book Service. New-Book standing order program expressly designed to meet the needs of academic libraries. The new program enables libraries to receive, automatically, new books in subject areas they select. Baker \& Taylor's professional library staff chooses titles of interest to academic libraries from all books published in the English language, both in the U.S. and abroad. The program is supported by the largest stock of University Press, scholarly and trade titles available from any one source.

B̄̄TAB (Baker \& Taylor's Automated Buying) A newly-developed computerized book ordering system for libraries. This exclusive data processing system will enable librarians to automate any or all of a library's book ordering operations, from book acquisition through fund accounting and budget control.

For further information, write to the BAKER \& TAYLOR DIVISION nearest you.

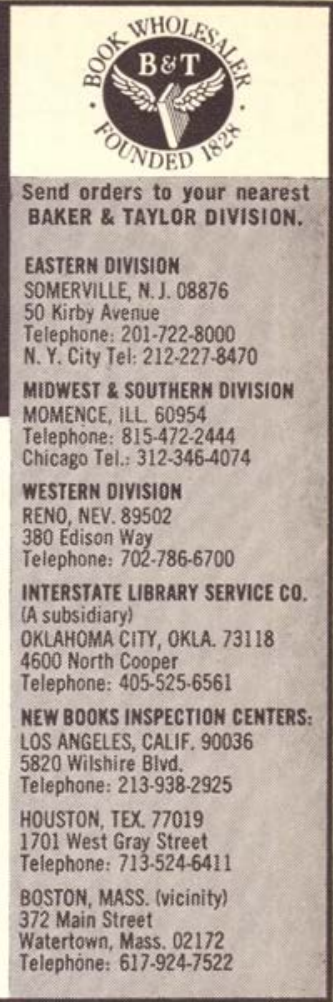

\section{The French Lieutenant's Woman}

The Mouse on Wall Street

Pop Corn \& Ma Goodness

\section{are notable}

The American Library Association presents three annual pamphlets that stimulate reading interest among adults, young adults, and children.

\section{Notable Books 196936 titles}

Notable Books Council, Adult Services Division, ALA

\section{Best Books for Young Adults $1969 \quad 22$ titles \\ Committee of the Young Adult Services Division, ALA}

Notable Children's Books 196964 titles

Book Evaluation Committee, Children's Services Division, ALA

- all titles annotated

- suitable for imprinting

- folded to fit a \#10 envelope
- leaflet format for distribution

- stimulates interest in current books and library use

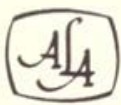

$\begin{array}{rr}100-\$ & 5.00 \\ 1,000-\$ & 37.50\end{array}$

250-\$ 11.00

$5,000-\$ 175.00$

$500-\$ 20.00$

$2,500-\$ 90.00$ 